\title{
Effects of Arbuscular Mycorrhizal Fungi Inoculation on a Wild Type Sorrel (Rumex acetosa) under Copper Stress
}

\author{
Fenghua Wang, Guangyuan Li, Jia Guo, and Shuangchen Chen
}

\begin{abstract}
Phytoremediation is becoming a potential method for remediation of heavy metal contaminated soil. The aim of this study is to discuss whether the sorrel absorbs copper $(\mathrm{Cu})$ from the soil, and whether arbuscular mycorrhizal fungi (AMF) inoculation enhances its capacity of $\mathrm{Cu}$ uptake. The experiment was conducted in plastic pots with three treatments: control, $600 \mathrm{mg} / \mathrm{kg} \mathrm{Cu}$, and $600 \mathrm{mg} / \mathrm{kg} \mathrm{Cu}$ plus $10 \mathrm{~g} \mathrm{AMF}$. The results showed that the sorrel accumulated $\mathrm{Cu}$ when planted in $\mathrm{Cu}$ contaminated soil. Furthermore, the more uptake $\mathrm{Cu}$, the more nitrogen $(N)$ and phosphorus $(P)$ was absorbed. When the sorrel was under copper stress, its peroxidase (POD) and catalase (CAT) activities increased, while superoxide dismutase (SOD) activity decreased compared with the control. Chlorophyll $(\mathrm{Chl})$ content decreased under copper stress, but no significant differences were observed in malondialdehyde (MDA) content. Although $\mathrm{Cu}$ stress inhibited the activity of soil urease, it didn't affect activities of soil cellulose, soil sucrase, and soil catalase. It also showed that AMF inoculation promoted the growth of sorrel, enhanced the capacity of $\mathrm{Cu}, \mathrm{N}, \mathrm{P}$, and potassium (K) uptake, but it didn't affect MDA and Chl content, POD activity, and CAT activities of sorrel. However, SOD activity was inhibited a little bit. The results also showed that AMF enhanced the activity of soil urease, inhibited activities of soil cellulose and soil sucrase. But it didn't influence the activity of soil CAT. It concluded that this sorrel was a $\mathrm{Cu}$ accumulating plant and AMF inoculation improved its capacity of $\mathrm{Cu}$ uptake.
\end{abstract}

Index Terms-Arbuscular mycorrhizal fungi (AMF), copper contamination, heavy metal, phytoextraction, phytoremediation.

\section{INTRODUCTION}

Copper $(\mathrm{Cu})$ is an essential micronutrient not only for living organisms, but also for the function of many enzymes. However, copper can cause toxic effects to organisms at high concentrations [1]. $\mathrm{Cu}$ pollution has become a significant environment issue at present due to human activities, such as mining, smelting, industrial waste disposal, sewage sludge application to agricultural soils, and the use of fertilizers and pesticides [2], [3]. Researchers are trying their best to find out appropriate technologies to remediate copper-contaminated soils. Phytoremediation which uses plants to remove metal pollutants from contaminated soil is being developed as a potential method for the remediation of heavy metal contaminated land [1]. Certain plant species have the ability to accumulate elevated amounts of toxic heavy metals [4], thus, they are becoming the best candidates for

Manuscript received August 15, 2015; revised October 21, 2015. This work was supported in part by the National Natural Science Foundation of China (31101536)

The authors are with the Forestry College, Henan University of Science and Technology, Luoyang, 471003, China (e-mail: fenghua123668@126.com). phytoremediation of contaminated soil. However, successful phytoremediation not only depends on the plant itself but also on many other factors. How to improve the accumulation capacity of heavy metals in plant is becoming a focus of current research. Ehylenediamine tetraacetate (EDTA) was widely studied to be applied to enhance heavy metal solubility in soil and increase heavy metal phytoavailability, as a result, the accumulation capacity of heavy metals in plants may be increased [5]-[7]. However, EDTA also posed a threat to soil quality and groundwater [8]. In recent years, arbuscular mycorrhizal fungi (AMF) have been shown to increase heavy metal uptake in plants [9]-[11]. Therefore, AMF may become a new chelate to improve phytoremediation of heavy metal contaminated soil.

Sorrel belongs to polygonaceae, Rumex acetosa $\mathrm{L}$, which is widely distributed in northwest China. It grows well in extreme environment, such as in low or high temperature, arid or water logging regions. Moreover, it grows fast with high biomass. The preliminary research found that a wild type sorrel grew well under $600 \mathrm{mg} / \mathrm{kg} \mathrm{Cu}$ stress without any inhibition. This study is going to study whether this sorrel absorbs $\mathrm{Cu}$ from the soil, and whether AMF inoculation enhances its capacity of $\mathrm{Cu}$ uptake. The influences of copper and AMF on sorrel and the rhizosphere environment will also be studied.

\section{MATERIALS AND METHODS}

\section{A. Plant Material and Experiment Design}

Sorrel seeds for this study were collected in Zhangbei county, Hebei province, northwest China. Seeds of sorrel were sown after accelerated germination, and transplanted when seedlings developed three leaves. The cultivation medium was a mixture of peat soil and vermiculite $(3: 1 \mathrm{w} / \mathrm{w})$ with $0.12 \% \mathrm{~N}$, extractable $\mathrm{Cd}, \mathrm{Cu}$, and $\mathrm{Zn}$ of $0.163,0.062$, and $0.441 \mathrm{mg} / \mathrm{kg}$. The media moisture was adjusted to $70 \%$. The experiment was designed as three treatments: $\mathrm{A}$ (control): no additional $\mathrm{Cu}$ and $\mathrm{AMF}$; B: $600 \mathrm{mg} / \mathrm{kg} \mathrm{Cu}$ (analytical reagent grade $\mathrm{CuCl}_{2}$ ); $\mathrm{C}: 600 \mathrm{mg} / \mathrm{kg}$ Cu plus $10 \mathrm{~g} \mathrm{AMF(dug} \mathrm{a}$ $5 \mathrm{~cm}$-dip hole in the media and added $10 \mathrm{~g}$ AMF into it). The experiment was conducted in plastic pots. Each pot contained $250 \mathrm{~g}$ of medium and two sorrel seedlings were planted. Put all of them in a chamber at $25 \pm 1^{\circ} \mathrm{C}$ to grow. Water losses were compensated with addition of distilled water during incubation. The experiment was carried out in a randomized complete block design with three replicates. Samples were collected for determination after being transplanted for 60 days. 


\section{B. Measurements of Plant Biomass and Growth}

10 plants per treatment were harvested to test fresh weight (FW), plant height, leaf area, and leaf numbers. Plants were washed in tap water before being gently washed twice with distilled water. Then the plants were dried at $80^{\circ} \mathrm{C}$ until a constant weight was achieved.

\section{Determination of $\mathrm{Cu}$ Content}

The $\mathrm{Cu}$ content was determined using the method described by Liu and Xiong[12]. $0.5 \mathrm{~g}$ dry weight (DW) of the sorrel were ground in a mortar, transferred to flasks, mixed with 20 $\mathrm{mL}$ of $\mathrm{HNO}_{3}$ and $\mathrm{HClO}_{4}(5: 3 \mathrm{v} / \mathrm{v})$, heated moderately at $80^{\circ} \mathrm{C}$ for about $8 \mathrm{~h}$. The digests were diluted and made up to $25 \mathrm{~mL}$ with $1 \mathrm{~mol} / \mathrm{LHNO}_{3}$. The copper concentration was determined by a flame atomic absorption spectrophotometer (Shanghai Precision Scientific Instrument Co. Ltd., China).

\section{Measurements of Soil Available Nitrogen $(N)$, Phosphorus $(P)$ and Potassium $(K)$ Contents}

Contents of soil available $N, P$, and $K$ were determined using air-dried soil. $\mathrm{N}$ was extract with $1 \mathrm{~mol} / \mathrm{L} \mathrm{KCl}$ (soil: water $=1: 10$ ) and analyzed by flow injection method. $\mathrm{P}$ was extracted with $0.5 \mathrm{~mol} / \mathrm{L} \mathrm{NaCHO}_{3}(\mathrm{pH} 8.5)($ soil: water $=1: 20)$ and then measured with $\mathrm{Mo}-\mathrm{Sb}$ method. $\mathrm{K}$ was extract with $\mathrm{NH}_{4} \mathrm{OAc}$ and measured by a flame atomic absorption spectrophotometry.

\section{E. Analysis of Chlorophyll (Chl) Content}

The Chl content was measured according to the method of Zhang and Fan [13]. Leaf tissue (0.5 g fresh weight) was homogenized in $80 \%$ acetone. The resulting solution was centrifuged and measured at $663 \mathrm{~nm}$ and $645 \mathrm{~nm}$ with a UV-visible spectrophotometer (Shanghai Precision Scientific Instrument Co. Ltd., China).

\section{F. Measurements of Malondialdehyde (MDA) Content}

MDA content was determined by thiobarbituric acid (TBA) reaction [13]. Approximately $0.2 \mathrm{~g}$ leaf samples were homogenized with $2 \mathrm{~mL}$ of $0.1 \%$ trichloroacetic acid (TCA) and centrifuged at $14,000 \mathrm{rpm}$ for $15 \mathrm{~min}$. After centrifugation, $1 \mathrm{ml}$ of the supernatant was mixed with $2.5 \mathrm{~mL}$ of $0.5 \%$ TBA in $20 \%$ TCA, and then incubated in hot water $\left(95^{\circ} \mathrm{C}\right)$ for $30 \mathrm{~min}$. Thereafter, it was cooled immediately on ice to stop the reaction and centrifuged at $10,000 \mathrm{rpm}$ for 30 min. Absorbance at $532 \mathrm{~nm}$ and $600 \mathrm{~nm}$ was determined, and MDA concentration was estimated by subtracting the non-specific absorption at $600 \mathrm{~nm}$ from the absorption at 532 $\mathrm{nm}$.

\section{G. Measurements of Plant Enzyme Activity}

Fresh leaf samples $(0.5 \mathrm{~g})$ were ground with liquid nitrogen and extracted in $5 \mathrm{~mL}$ of $50 \mathrm{mM}$ potassium phosphate buffer (pH7.0). The supernatants were the solution of crude enzyme. All measurements were carried out according to the methods of Zhang and Fan [13].

The peroxidase (POD) activity: The assay mixture $(2.5 \mathrm{~mL})$ contained $5 \mathrm{mM}$ guaiacol, $10 \mathrm{mM} \mathrm{H}_{2} \mathrm{O}_{2}, 50 \mathrm{mM}$ potassium phosphate buffer (pH 7.0), and $100 \mu \mathrm{L}$ crude enzyme solution. The activity was expressed in units per gram of fresh weight $(\mathrm{U} / \mathrm{gFW})$, where one unit of enzyme activity is defined as a change in absorbance unit per minute.
Superoxide dismutase (SOD) activity: The reaction solution contained $14.5 \mathrm{mmol} / \mathrm{L}$ Met $162 \mathrm{~mL}, 30 \mu \mathrm{M}$ EDTA-2Na $0.6 \mathrm{~mL}$, phosphate buffered saline (PBS) $5.4 \mathrm{~mL}$, $2.25 \mathrm{mM}$ nitroblue tetrazolium (NBT) $6 \mathrm{~mL}, 60 \mu \mathrm{M}$ riboflavin $6 \mathrm{~mL}$. Added $3 \mathrm{~mL}$ reaction solution and $40 \mu \mathrm{L}$ crude enzyme solution in reaction tube, put them under light incubator (light intensity $4000 \mathrm{lux}$ ). When the colour was changing, moved them away from the light incubator and assayed at OD560. The activity was expressed as U/gFW, where one $U$ was defined as that amount of enzyme causing half the maximum inhibition of NBT reduction.

Catalase(CAT) activity: added $0.3092 \mathrm{~mL} 30 \% \mathrm{H}_{2} \mathrm{O}_{2}$ in $200 \mathrm{mLPBS}(150 \mathrm{mmol} / \mathrm{L}, \mathrm{pH}$ 7.0) to make reaction solution. Added $3 \mathrm{~mL}$ reaction solution and $100 \mu \mathrm{L}$ crude enzymes in a reaction tube, read the dynamic A240 changes. The activity was expressed as $\mathrm{U} / \mathrm{gFW}$, where one unit was defined as the loss of absorbance at $240 \mathrm{~nm}$ per minute.

\section{H. Assessments of Soil Enzyme Activity}

Soil enzyme activities were measured as described by Li et al. [14]. All enzyme activities were assayed by air dried weight of soil (DW). All enzyme activity values presented were averages obtained from assays performed in triplicate.

Urease activity was measured using phenol-sodium hypochlorite colorimetry method and the activity was expressed as mg $\left(\mathrm{NH}_{4}{ }^{+}-\mathrm{N}\right) / \mathrm{g}$ DW $24 \mathrm{~h}$. Sucrase activity was measured using 3, 5-dinitrosalicylic acid colorimetric method and expressed as mg (glucose) /g DW 24h. The catalase activity was determined using $\mathrm{KMnO}_{4}$ method and expressed as $\mathrm{mg}\left(\mathrm{KMnO}_{4}\right) / \mathrm{g} \mathrm{DW} \cdot 30 \mathrm{~min}$. The cellulase activity was assayed by nelson-somogyi colorimetric method and expressed as mg (glucose)/ g DW 72h.

\section{Statistical Analysis}

All data were statistically analyzed using the SPSS10 statistical software by one-way ANOVA, followed by the Tukey test, using $P<0.05$ as significant.

\section{RESULTS}

\section{A. $\mathrm{Cu}$ Contents of Sorrels}

The $\mathrm{Cu}$ contents of sorrels under different treatments were shown in Fig. 1. It showed that $\mathrm{Cu}$ content of treatment $\mathrm{B}$ was higher than that of control (A), which indicated that the sorrels accumulated $\mathrm{Cu}$. Among the three treatments, $\mathrm{Cu}$ content of $\mathrm{C}$ was the highest, about 2.46 times of $\mathrm{B}$, which meant that $\mathrm{AMF}$ improved the sorrel's capacity of $\mathrm{Cu}$ accumulation.



A: Control; B: $600 \mathrm{mg} / \mathrm{kg} \mathrm{Cu}$; $\mathrm{C}$ : $600 \mathrm{mg} / \mathrm{kg} \mathrm{Cu}+\mathrm{AMF}$ Fig. 1. Cu content of sorrel. 


\section{B. Contents of Soil Available N, $P$ and $K$}

Contents of soil available $\mathrm{N}, \mathrm{P}$ and $\mathrm{K}$ were measured to check whether $\mathrm{Cu}$ and AMF influenced nutrition uptake of sorrel. The results were shown in Table I. The $\mathrm{N}$ and $\mathrm{P}$ contents of $\mathrm{B}$ were lower than those of A, respectively. It concluded that the capacity of $\mathrm{N}$ and $\mathrm{P}$ uptake increased under $\mathrm{Cu}$ stress. However, No significant differences exited between $\mathrm{A}$ and $\mathrm{B}$ in $\mathrm{K}$ content, which meant that $\mathrm{Cu}$ stress didn't affect $\mathrm{K}$ content. When inoculation with AMF (treatment $\mathrm{C}$ ), the contents of soil available $\mathrm{N}, \mathrm{P}$, and $\mathrm{K}$ all decreased, which indicated that AMF promoted the absorption of $\mathrm{N}, \mathrm{P}$ and $\mathrm{K}$.

\begin{tabular}{cccc}
\multicolumn{4}{c}{ TABLE I: ConTENTS OF SoIL Available $N, P$ AND $K$} \\
\hline Treatment & $\begin{array}{c}\text { N Content } \\
\mathrm{mg} / \mathrm{kg}\end{array}$ & $\begin{array}{c}\text { P Content } \\
\mathrm{mg} / \mathrm{kg}\end{array}$ & $\begin{array}{c}\mathrm{K} \text { Content } \\
\mathrm{mg} / \mathrm{kg}\end{array}$ \\
\hline $\mathrm{A}$ & 552 & 214 & 31.8 \\
$\mathrm{~B}$ & 329 & 145 & 31.2 \\
$\mathrm{C}$ & 317 & 125 & 25.5 \\
\hline
\end{tabular}

A: Control; B: $600 \mathrm{mg} / \mathrm{kg} \mathrm{Cu}$; $\mathrm{C}$ : $600 \mathrm{mg} / \mathrm{kg} \mathrm{Cu}+\mathrm{AMF}$, the same followed.

\section{Plant Biomass and Growth Indexes}

The results showed that there were no significant differences between A and B in fresh weight (Table II) which suggested that copper stress did not affect the growth of sorrel. Therefore, this sorrel may be a copper tolerant plant. All indexes except leaf numbers increased when inoculation with AMF. So, we concluded that AMF had a positive effect on the growth of sorrel under copper stress.

\section{Contents of MDA and Chl}

MDA is one of the final products of polyunsaturated fatty acids peroxidation. MDA level is commonly known as a marker of oxidative stress and the antioxidant status in plants. In the study, no significant differences were observed in MDA content among three treatments (Table III), which suggested that neither copper nor AMF affect the membrane lipid peroxidation of sorrel.

TABLE II: MORPHOLOGICAL PARAMETER OF SORREL

\begin{tabular}{cllll}
\hline Treatment & Fresh weight & Plant height \\
$\mathrm{cm}$ & $152.67 \pm 2.09 \mathrm{a}$ & $19.87 \pm 0.35 \mathrm{a}$ & $\begin{array}{l}\text { Leaf area } \\
\mathrm{cm}^{2}\end{array}$ & $27.93 \pm 0.25 \mathrm{a}$ \\
\hline $\mathrm{A}$ & $147.28 \pm 1.25 \mathrm{a}$ & $19.57 \pm 0.31 \mathrm{a}$ & $27.53 \pm 1.70 \mathrm{a}$ & $6.67 \pm 0.58 \mathrm{a}$ \\
$\mathrm{B}$ & $161.71 \pm 3.27 \mathrm{~b}$ & $26.23 \pm 1.01 \mathrm{~b}$ & $28.83 \pm 0.25 \mathrm{a}$ & $7.00 \pm 0.00 \mathrm{a}$ \\
\hline
\end{tabular}

TABLE III: PHYSIOLOGY PARAMETERS OF SORREL

\begin{tabular}{cll} 
Treatment & $\begin{array}{l}\text { MDA content } \\
\mathrm{mg} / \mathrm{g} \mathrm{FW}\end{array}$ & $\begin{array}{l}\text { Chl content } \\
\mathrm{mg} / \mathrm{gFW}\end{array}$ \\
\hline $\mathrm{A}$ & $6.47 \pm 0.66 \mathrm{a}$ & $2.67 \pm 0.04 \mathrm{a}$ \\
$\mathrm{B}$ & $5.35 \pm 1.46 \mathrm{a}$ & $2.76 \pm 0.03 \mathrm{~b}$ \\
$\mathrm{C}$ & $5.68 \pm 1.36 \mathrm{a}$ & $2.83 \pm 0.01 \mathrm{~b}$ \\
\hline
\end{tabular}

The results also showed that $\mathrm{Chl}$ content of $\mathrm{B}$ was lower than that of A (Table III), which was to say Chl synthesis was inhibited by copper. No significant differences were observed between $\mathrm{B}$ and $\mathrm{C}$, which indicated that $\mathrm{AMF}$ had no influences on $\mathrm{Chl}$ synthesis.

\section{E. Activities of Plant Enzymes}

TABLE IV: ACTIVITIES OF SORREL ENZYMES

\begin{tabular}{cccl}
\hline Treatment & $\begin{array}{c}\text { POD activity } \\
\text { U/g FW }\end{array}$ & $\begin{array}{c}\text { SOD activity } \\
\text { U/g FW }\end{array}$ & $\begin{array}{l}\text { CAT activity } \\
\text { U/g FW }\end{array}$ \\
\hline A & $5.17 \pm 0.58 \mathrm{a}$ & $79.40 \pm 5.43 \mathrm{~d}$ & $2.45 \pm 0.21 \mathrm{a}$ \\
B & $52.33 \pm 1.26 \mathrm{~b}$ & $63.10 \pm 4.36 \mathrm{c}$ & $3.28 \pm 0.42 \mathrm{~b}$ \\
C & $49.00 \pm 1.32 \mathrm{~b}$ & $34.19 \pm 5.80 \mathrm{a}$ & $3.32 \pm 0.27 \mathrm{~b}$ \\
\hline
\end{tabular}

POD activities of both $\mathrm{B}$ and $\mathrm{C}$ were higher than those of $\mathrm{A}$ (Table IV), in other words POD activity increased under copper stress. The increasing POD can eliminate reactive oxygen species (ROS) to avoid injuries, which was probably the reason why no changes happened on MDA content under copper stress. The result also showed that AMF did not affect POD activity. However, Change of SOD activity was different from POD. SOD activity of B was lower than that of A (Table IV). Therefore, SOD activity was inhibited by extra
$\mathrm{Cu}$. It was also shown that SOD activity went much lower when inoculation with AMF, which suggested that AMF may be an inhibition factor for SOD activity. CAT activities of B and $\mathrm{C}$ were all higher than those of $\mathrm{A}$ (Table IV), which indicated that $\mathrm{Cu}$ stress promoted the activity of ACT, thus the ability to remove ROS improved. No significant differences were observed between $\mathrm{B}$ and $\mathrm{C}$. Therefore, AMF did no influences on CAT activity.

\section{F. Activities of Soil Enzyme}

Activities of soil enzymes were shown in Table V. No significant differences were observed in cellulose activity, sucrase activity, and catalase activity between $\mathrm{A}$ and $\mathrm{B}$, which indicated that $\mathrm{Cu}$ stress did not affect activities of above soil enzymes. The activities of cellulose and sucrase of $\mathrm{C}$ were lower than those of B respectively, which suggested that AMF inhibited the activities of these two soil enzymes. No significant differences were observed in soil CAT activity among these three treatments. The Table $\mathrm{V}$ also showed that urease activity of $\mathrm{B}$ was lower than that of $\mathrm{A}$, which meant that urease activity was inhibited by $\mathrm{Cu}$ stress. However its activity increased when inoculation with AMF, which meant that urease activity was promoted by AMF.

\begin{tabular}{cllll}
\multicolumn{5}{c}{ TABLE V: ACTIVITIES OF SOIL ENZYMES } \\
\hline Treatment & $\begin{array}{c}\text { Cellulose } \\
\mathrm{mg} / \mathrm{g} \mathrm{DW}\end{array}$ & $\begin{array}{l}\text { Sucrase } \\
\mathrm{mg} / \mathrm{g} \mathrm{DW}\end{array}$ & $\begin{array}{l}\text { Catalase } \\
\mathrm{mg} / \mathrm{g} \mathrm{DW}\end{array}$ & $\begin{array}{l}\text { Urease } \\
\mathrm{mg} / \mathrm{g} \mathrm{DW}\end{array}$ \\
\hline $\mathrm{A}$ & $0.12 \pm 0.00 \mathrm{~b}$ & $0.28 \pm 0.00 \mathrm{~b}$ & $1.99 \pm 0.02 \mathrm{a}$ & $3.17 \pm 0.04 \mathrm{~b}$ \\
$\mathrm{~B}$ & $0.11 \pm 0.00 \mathrm{~b}$ & $0.27 \pm 0.00 \mathrm{~b}$ & $1.87 \pm 0.09 \mathrm{a}$ & $1.55 \pm 0.29 \mathrm{a}$ \\
$\mathrm{C}$ & $0.07 \pm 0.01 \mathrm{a}$ & $0.05 \pm 0.01 \mathrm{a}$ & $1.85 \pm 0.11 \mathrm{a}$ & $3.33 \pm 0.04 \mathrm{~b}$
\end{tabular}




\section{DISCUSSION}

Copper is an essential micronutrient for plant growth and development, but it is also a heavy metal element that posed serious environmental and human health risks [3]. In some plants, $\mathrm{Cu}$ had been shown to reduce biomass, caused chlorotic symptoms and necrosis, inhibited plant growth [15], caused changes in physiological indexes [16]-[18]. Remediation was widely studied to recovery $\mathrm{Cu}$ contaminated soil. Remediation consisted of two fundamental methods, one was physical and chemical remediation, the other was phytoremediation [19]. Physical and chemical remediation had serious limitations and adverse effects such as destruction of soil structure, secondary pollution, and huge costs. Phytoremediation was an economically and ecologically appropriate clean up procedures [17], [20], and it was viewed as a more promising remediation technology [16].

In the present study, the growth of sorrel was not significantly inhibited by copper. $\mathrm{Cu}$ determination proved that this sorrel was a copper accumulating plant and it can absorb $\mathrm{Cu}$ from $\mathrm{Cu}$ contaminated soil. Therefore, this sorrel may become a proper plant for phytoremediation of $\mathrm{Cu}$ contaminated sites. However, its capacity of $\mathrm{Cu}$ uptake was still low, only was $67.10 \mathrm{mg} / \mathrm{kg}$. How to improve the accumulation of heavy metals in plants is also becoming a focus of current research. Some studies showed that the ageing of soil had a significant influence on the mobility and the bioavailability of heavy metals [21]-[25], and subsequently influenced plant uptake during phytoremediation. Soil microbes played significant roles in recycling of plant nutrients, maintenance of soil structure, detoxification of noxious chemicals [22], [26], altering metal bioavailability in the soil [20], [27]. Therefore soil microorganisms had the potential to improve the effect of phytoremediation [28]. This study used AMF to regulate repair capacity of sorrel. The results showed that inoculation with AMF was advantageous to copper accumulation. $\mathrm{Cu}$ content of sorrel reached up to $172.32 \mathrm{mg} / \mathrm{kg}$, which was about 2.57 times of that without AMF inoculation. Therefore, it concluded that AMF inoculation was an appropriate method to improve phytoremediation of sorrel. This result agreed with that of Bissonnette et al. [9], who concluded that phytoextraction was enhanced by inoculation with AMF due to their effect on heavy metal uptake in plants. To the mechanism of AMF improvement of heavy metal uptake, David et al. [29] concluded that AMF immobilized heavy metals within root tissue and increased shoot concentrations of heavy metals. However, even if AMF did not improve accumulation of heavy metals in plants, they could still enhance heavy metal tolerance, allowing plants to build more biomass and therefore extract more metal [29].

\section{REFERENCES}

[1] A. X. Du, L. X. Cao, R. D. Zhang, and R. Pan, "Effects of a copper-resistant fungus on copper adsorption and chemical forms in soils," Water Air Soil Pollut, vol. 201, pp. 99-107, July 2009.

[2] L. Wei, C. Luo, X. Li, and Z. Shen, "Copper accumulation and tolerance in chrysanthemum coronarium L. and sorghum sudanense L," Arch Environ Con Tox, vol. 55, pp. 238-246, August 2008.

[3] G. E. Uwumarongie-Ilori and F. E. Okieimen, "Pytoremediation of chromated copper arsenate contaminated soil by maize (Zea mays L.)," J Biodiv Environ Sci, vol. 1, pp. 1-6, April 2011.
[4] J. Brunet, A. Repellin, G. Varrault, J. Terryn, and Y. Zuily-Fodil, "Lead accumulation in theroots of grass pea (Lathyrus sativus L.): A novel plant for phytoremediation systems?" Comptes Rendus Biologies, vol. 331, pp. 859-864, September 2008.

[5] H. Diwan, A. Ahmad, and M. Iqbal, "Uptake-related parameters as indices of phytoremediation potential," Biologia, vol. 65, pp. 1004-1011, December 2010.

[6] M. S. Kambhampati and V. T. Vu, "EDTA enhanced phytoremediation of copper contaminated soils using chickpea (Cicer aeritinum L.)," Bull Environ Contam Toxicol, vol. 91, pp. 310-313, September 2013.

[7] V. K. Sinhal, A. Srivastava, and V. P. Singh, "EDTA and citric acid mediated phytoextraction of $\mathrm{Zn}, \mathrm{Cu}, \mathrm{Pb}$ and $\mathrm{Cd}$ through marigold (Tagetes erecta)," J Environ Biol, vol. 31, pp. 255-259, May 2010.

[8] B. Kos and D. Štan, "Influence of a biodegradable ([S,S]-EDDS) and non- degradable (EDTA) chelate and hydrogel modified soil water sorption capacity on $\mathrm{Pb}$ phytoextraction and leaching," Plant Soil, vol. 253, pp. 403-411, June 2003.

[9] L. Bissonnette, M. Labrecque, and M. S. T. Arnaud, "Phytoextraction of heavy metals by two salicaceae clones in symbiosis with arbuscular mycorrhizal fungi during the second year of a field trial," Plant Soil, vol. 332, pp. 55-67, July 2010.

[10] K. Turnau, T. Anielska, P. Ryszka, S. Gawroński, B. Ostachowicz, and A. Jurkiewicz, "Establishment of arbuscular mycorrhizal plants originating from xerothermic grasslands on heavy metal rich industrial wastes-new solution for waste revegetation," Plant Soil, vol. 305, pp. 267-280, April 2008.

[11] F. Y. Wu, Y. L. Bi, H. M. Leung, Z. H. Ye, X. G. Lin, and M. H. Wong, "Accumulation of $\mathrm{As}, \mathrm{Pb}, \mathrm{Zn}, \mathrm{Cd}$ and $\mathrm{Cu}$ and arbuscular mycorrhizal status in populations of cynodon dactylon grown on metal-contaminated soils," Appl Soil Ecol, vol. 44, pp. 213-218, March 2010

[12] J. Liu and Z. T. Xiong, "Differences in accumulation and physiological response to copper stress in three populations of Elsholtzia haichowensis S," Water Air Soil Pollut, vol. 168, pp. 5-16, November 2005.

[13] L. J. Zhang and J. J. Fan, Experiments for plant physiology China Agricultural University Press, Beijing, 2007.

[14] Z. G. Li, Y. M. Luo, and Y. Teng, Research Methods for Soil and Soil Microorganisms, Science Press, Beijing, 2008.

[15] I. Yruela, "Copper in plants: acquisition, transport and interactions," Funct Plant Biol, vol. 36, pp. 409-430, May 2009.

[16] M. Bačkor, J. Kováčik, A. Dzubaj, and M. Bačkorová, "Physiological comparison of copper toxicity in the lichens Peltigera rufescens (Weis) Humb. and Cladina arbuscula subsp. Mitis (Sandst.) Ruoss," Plant Growth Regul, vol. 58, pp. 279-286, July 2009.

[17] S. Kathi and A. B. Khan, "Phytoremediation approaches to $\mathrm{PAH}$ contaminated soil," Indian J Sci Tech, vol. 4, pp. 56-63, January 2011.

[18] K. Praveen, K. T. Rajesh, and N. S. Parma, "Modulation of copper toxicity-induced oxidative damage by excess supply of iron in maize plants," Plant Cell Rep, vol. 27, pp. 399-409, February2008.

[19] N. Y. Li, Z. A. Li, Q. L. Fu, and P. Zhuang, "Agricultural technologies for enhancing the phytoremediation of cadmium-contaminated soil by Amaranthus hypochondriacus L," Water Air Soil Pollut, vol. 224, pp. 1673-1681, September 2013.

[20] S. P. McGrath, F. J. Zhao, and E. Lombi, "Plant and rhizosphere processes involved in phytoremediation of metal-contaminated soils" Plant Soil, vol. 232, pp. 207-214, May 2001.

[21] C. Chigbo and L. Batty, "Phytoremediation potential of Brassica juncea in Cu-pyrene co-contaminated soil: comparing freshly spiked soil with aged soil," J Environ Manage, vol. 129, pp. 18-24, November 2013.

[22] Z. Filip, "International approach to assessing soil quality by ecologically-related biological parameters," Agric Ecosyst Environ, vol. 88, pp. 169-174, February 2002.

[23] A. Lu, S. Zhang, X. Qin, W. Wu, and H. Liu, "Aging effect on the mobility and bioavailability of Copper in soil," J Environ Sci, vol. 21, pp. 173-178, February 2009.

[24] J. Nouri, B. Lorestani, N. Yousefi, N. Khorasani, A. H. Hasani, S. Seif, and M. Cheraghi, "Phytoremediation potential of native plants grown in the vicinity of Ahangaran leadezinc mine (Hamedan, Iran)," Environ Earth Sci, vol. 62, pp. 639-644, February 2011.

[25] K. A. Whittinghall and S. E. Hobbie, "Effects of landscape age on soil organic matter processing in northern Alaska," Soil Sci Soc Am J, vol. 75, pp. 907-917, May 2011.

[26] L. Elsgaard, S. O. Petersen, and K. Debosz, "Effects and risk assessment of linear alkylbenzene sulfonates in agricultural soil. 1. Short-term effects on soil microbiology," Environ Toxicol Chem, vol. 20, pp. 1656-1663, August 2001 
[27] H. A. Lasat, "Phytoextraction of toxic metals: A review of biological mechanisms," J Environ Qual, vol. 31, pp. 109-120, January 2002.

[28] S. Kärenlampi, H. Schat, J. Vangronsveld, J. A. C. Verkleij, D. Lelie, M. Mergeay, and A. I. Tervahauta, "Genetic engineering in the improvement of plants for phytoremediation of metal polluted soils," Environ Pollut, vol. 107, pp. 225-231, February 2000.

[29] F. David, "Arbuscular mycorrhizal fungi can benefit heavy metal tolerance and phytoremediation," J Nat Resour Life Sci Edu, vol. 41, pp. 23-26, 2012.

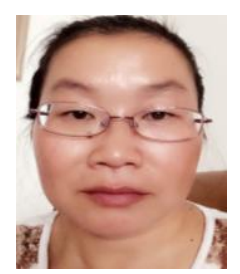

Fenghua Wang was born in 1972 in Sichuan China. In 1995, she received her B.Sc. in agriculture from Southwest Agriculture University, China. In 1998, she received her M.Sc in agriculture from the same university. In 2003, she received Ph.D in agriculture in Fujian Agriculture and Forestry University. 